\title{
AN ARCHAEOMETRIC AND ARCHAEOLOGICAL APPROACH TO HELLENISTIC- EARLY ROMAN CERAMIC WORKSHOPS IN GREECE: CONTRIBUTION TO DATING
}

\author{
DESPINA KONDOPOULOU ${ }^{1, *}$, IRENE ZANANIRI ${ }^{2}$, CHRISTINA RATHOSSI $^{3}$, EMANUELA DE MARCO $^{1}$, \\ VASILEIOS SPATHARAS ${ }^{1}$, and ELENI HASAKI ${ }^{4}$
}

${ }^{1}$ Department of Geophysics, School of Geology, Aristotle University of Thessaloniki, P.O. Box 352-1, Thessaloniki 54124, Greece.

${ }^{2}$ Institute of Geology and Mineral Exploration, 1 Spirou Loui str., Olympic Village (Entrance C), Acharnae 13677, Greece.

${ }^{3}$ Sector of Earth Materials, Department of Geology, University of Patras, Rio Patra 26504, Greece.

${ }^{4}$ School of Anthropology and Department of Classics, University of Arizona, P.O. Box 210030, Tucson, AZ 85712-0030, USA.

*Corresponding author: despi@geo.auth.gr.

\begin{abstract}
The present article comprises a multidisciplinary archaeometric approach for the study of Hellenistic and Early Roman kilns in Greece. A collection of previously published and new archaeomagnetic data are combined with new results from mineralogical analytical experiments. The sampled material came from four areas, covering different geological contexts: Katerini, Olympiada, and Polymylos in mainland Greece, and the island of Paros. Extensive rock-magnetic experiments, including identification of the dominant ferromagnetic minerals present, their domain state, and mineralogical alterations during laboratory treatments, have been carried out in order to examine the magnetic properties of the studied materials and prove their suitability for reliable archaeomagnetic determinations. Magnetic cleaning provided well-defined archaeomagnetic directions, and archaeointensity measurements were carried out using both the Thellier-Thellier and Triaxe protocols. Information from both magnetic and mineralogical properties referring to firing conditions is further discussed along with archaeological information. Finally, a new dating of the four sites together with other structures of similar age was carried out using the Pavón-Carrasco model.
\end{abstract}

Keywords: archaeomagnetism, mineralogical analysis, firing temperature, ceramic workshop, Hellenistic/Early Roman.

\section{INTRODUCTION}

In spite of the considerable progress made in recent decades, the improvement of dating techniques for correlating archaeological materials remains essential. Among commonly used scientific dating techniques, such as radiocarbon analysis, dendrochronology, and luminescence, and their various advantages and disadvantages, archaeomagnetic dating is becoming increasingly important (Aitken 1999).

Archaeomagnetism is based on the principle that well-fired objects and structures, such as bricks, kilns, or pottery, acquire a magnetization in the geomagnetic field as they cool down to ambient temperature. The pioneering works of Thellier and Thellier (1959) and Thellier (1981) have shown that archaeological materials record both the direction and intensity of the geomagnetic field in which they last cooled, and that this recorded magnetization can be used to characterize the behavior of the Earth's magnetic field in the past. Where a dated record of geomagnetic change has been established, measurements of magnetization can be used to date the last heating event in the studied structure (Kovacheva et al. 1998; Le Goff et al. 2002; Pavón-Carasco et al. 2009 and references therein).
The discipline of archaeomagnetism has considerably expanded in recent decades and resulted in a number of databases and geomagnetic field models (Korte et al. 2005; Genevey et al. 2008; Donadini et al. 2009; Pavón-Carasco et al. 2009, 2010; Tema and Kondopoulou 2011; Gómez-Paccard et al. 2012). The construction of local secular variation curves has resulted in considerably improving the dating in addition to fortifying our knowledge about the geomagnetic field's properties and evolution.

Systematic research has been conducted for several years in numerous archaeological sites in Greece, spanning broad time periods, by applying the archaeomagnetic method (Spatharas 2005; De Marco 2007). The scope of this research was to provide accurate data for a robust secular variation curve (De Marco et al. 2008b, 2014; Tema et al. 2012) and to date archaeological features where possible - that is, where the geomagnetic field variations versus time had already been determined.

Several of these sites belong to the Hellenistic period (323$31 \mathrm{BC}$ ), for which pottery manufacture procedures are well documented in Greece. The basic archaeomagnetic data from the above workshops were reported in previous studies (Spatharas 2005; Evans 2006; De Marco et al. 2008a, b; Spatharas et al. 2011). 
Nevertheless, several problems arose while obtaining these data and, despite the large amount of available material, an unexpectedly small number of satisfactory results - mostly for archaeointensities - were obtained. The complex issue of successful intensity studies is still under investigation. The purpose of the present study is to re-examine these results in a general context of Hellenistic and Early Roman ceramic workshops, in an attempt to improve this outcome. Workshops, by definition, have the advantage of providing at least two structures that share common clay properties and mostly comparable ages; thus, at such sites the potential for a successful study is maximized. Studies on ceramic workshops or individual kilns have revealed the importance of the firing conditions and their impact on archaeointensity studies. Temperature distribution within a kiln is of great importance for archaeointensity determinations because it strongly affects several magnetic parameters. Though the matter is by no means fully understood, some experimental studies have been carried out. Spassov and Hus (2006) investigated baking temperatures in a Roman pottery kiln by using rock magnetic properties. They showed that blackish- and grayish-colored kiln parts are not suitable for intensity determinations because they strongly alter during laboratory heating, whereas brownish-colored material seems to be the most suitable. The authors estimate ancient baking temperatures at around $800-950^{\circ} \mathrm{C}$ based on a mathematical model. These temperatures would decrease to only $600^{\circ} \mathrm{C}$ at a distance of $65-80 \mathrm{~mm}$ from the combustion chamber. In another study, Aidona et al. (2008) examined a Roman-style gold furnace experimentally built in order to monitor the spatial distribution of magnetic parameters through a $25-\mathrm{cm}$-long to 10 -cm-high brick, situated in the center of the fired area. Their main conclusion was that the effect of fire was significant up to $5 \mathrm{~cm}$ depth, whereas its lateral effect was limited to a distance of 8-10 cm. In a modern Spanish kiln, Catanzariti et al. (2008) report several variations of the magnetic properties even within and between bricks. Finally, Morales et al. (2011) designed a complex archaeointensity experiment on an open kiln founded in AD 1815 in Mexico. They detected significant thermal gradients inside the kiln, as well as different cooling rates likely to seriously affect the intensity results. The existence of high vertical gradients (up to $300^{\circ} \mathrm{C}$ ) and moderate lateral ones (up to $100^{\circ} \mathrm{C}$ ) might create major differences in intensity determinations.

Therefore, in the present study we use previously published archaeomagnetic data from four Hellenistic-Early Roman workshops together with

a. Further archaeointensity measurements from Paros and Olympiada, where successful Thellier results were limited, by applying a different method, namely the Triaxe protocol (Le Goff and Gallet 2004).

b. Extensive petrographic and mineralogical experiments, which can provide detailed information about firing temperatures and clay composition as well as firing environments and possible alterations not detectable through the usual magnetic experiments.

The primary goal of the present study is to cross-check whether or not the mineralogical-petrographic information, together with archaeological information, can contribute to the successful selection of samples for archaeointensity analysis. Apart from the four workshops presented here, several individual kilns of the same period have been studied so far (Figure S1, available in the online supplement to this article; Table 5). However, we are limiting the present research solely to workshops to obtain more information on the potential of the methods used to detect clay variations, not only within the same kiln but also within more than one kiln in the same workshop. Archaeomagnetic dating within a workshop can be a useful trial and confirmation of the method.

\section{ARCHAEOLOGICAL CONTEXT AND LOCATION OF THE STUDIED SITES}

Hellenistic Greece (323-31 BC) was a period of prosperity, when people and goods moved fluidly around the Hellenistic kingdoms. The large production of pottery and clay vessels, unearthed in excavations in Greece and the broader Mediterranean region, allowed for this aspect of the Hellenistic period in Greece to be very well documented archaeologically.

Ceramic workshops during Hellenistic and Early Roman times were spread throughout numerous places in Greece [for a thorough review, see Hasaki (2002)]. In general, a kiln's lifetime averages 20-30 years, although cases have been reported of more, allowing a good constraint for the magnetic field recorded in the area. The most commonly used material for the construction of kilns is fired clay, an unrefined material, but comprising what was locally available. A combination of a smooth, sticky clay with another one containing more sand and coarse particles is often ideal, because such a mixture will resist cracking during firing (Jones 1993). The use of baked clays in archaeomagnetism has been thoroughly investigated and procedures for optimum selection of samples have been proposed (Jordanova et al. 2003). The firing phase was subdivided into three equally important stages: prefiring, firing, and cooling. The underlying principle is that the temperature must rise slowly (prefiring), continue rising steadily until it reaches 900 $1000^{\circ} \mathrm{C}$ (with the exception of certain coarseware that can be fired at lower temperatures), remain there for some hours (firing), and finally decrease steadily (cooling). Not all the places inside a kiln (see Appendix A: The ceramic kiln) had the same temperature at all times. In general, the prefiring lasted almost as long as the firing itself, and the cooling period as long as the prefiring and the firing together (Spassov and Hus 2006; Morales et al. 2011).

The choice of the four workshops presented here (Katerini, Olympiada, Polymylos, and Paros) was based, apart from material availability, on the following factors: geographic distribution within different geological environments (Figure S1), existence of at least three kilns having functioned within them, and available archaeological studies of their characteristics (see Appendix B: Description of studied sites). Such features allow a thorough examination of their potential for successful archaeomagnetic studies and possible explanation for failures. In general, all the inves- 
tigated structures are kilns used for firing architectural ceramics (such as tiles and bricks) or pottery (e.g. amphorae and smaller vessels). The types of material sampled include burnt clay, bricks, and tiles, depending on the construction of each particular structure (Figure 1). All sites were archaeologically dated (Tables 1-3)
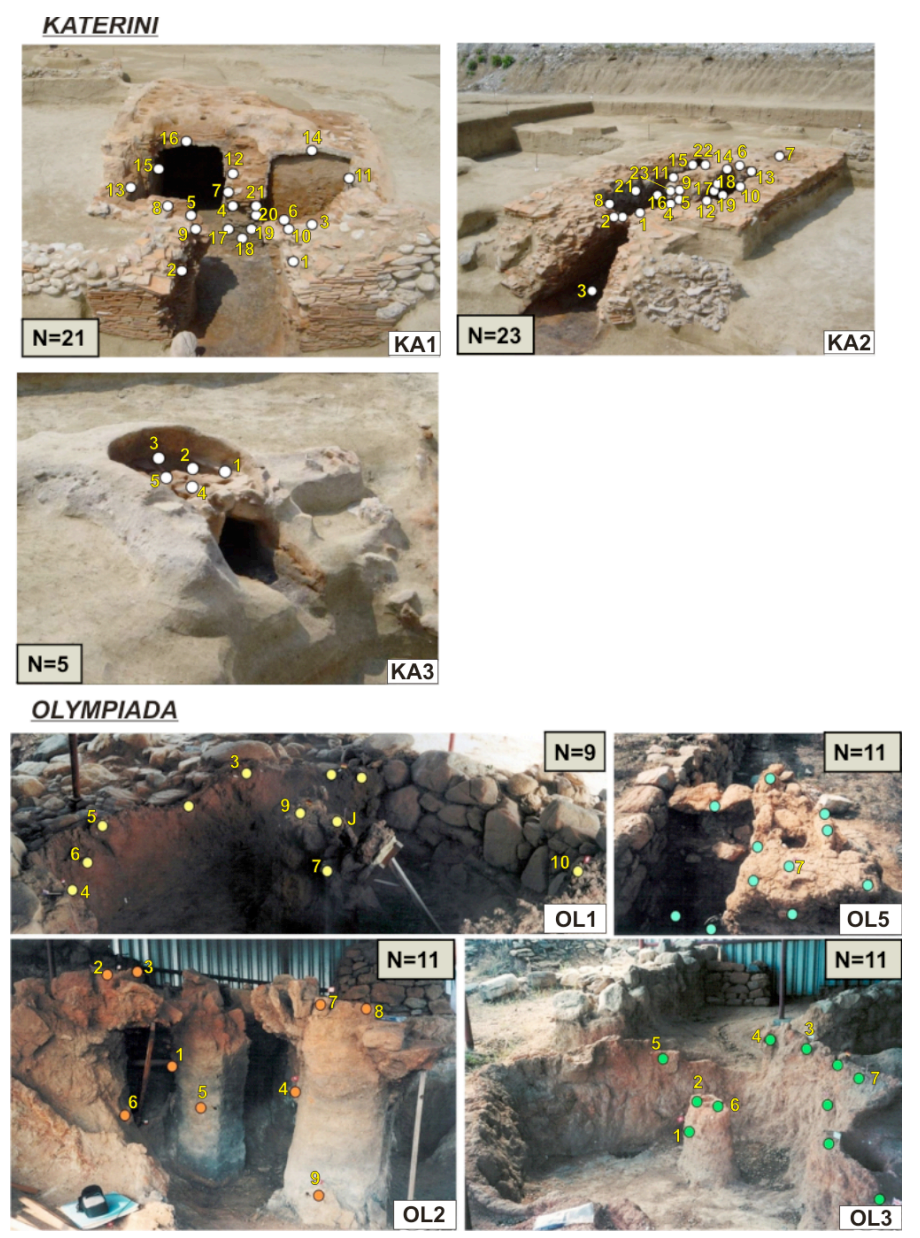

through their architectural style, ceramic typology, and agediagnostic objects, like coins and specific artifacts. Moreover, the archaeomagnetic study allowed additional dating for the studied sites and a comparison of the resulting ages was possible, leading to eventual modifications of their initial age classification.
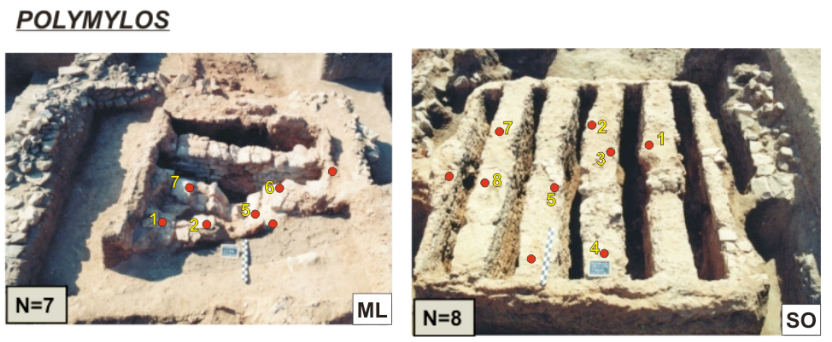

PAROS
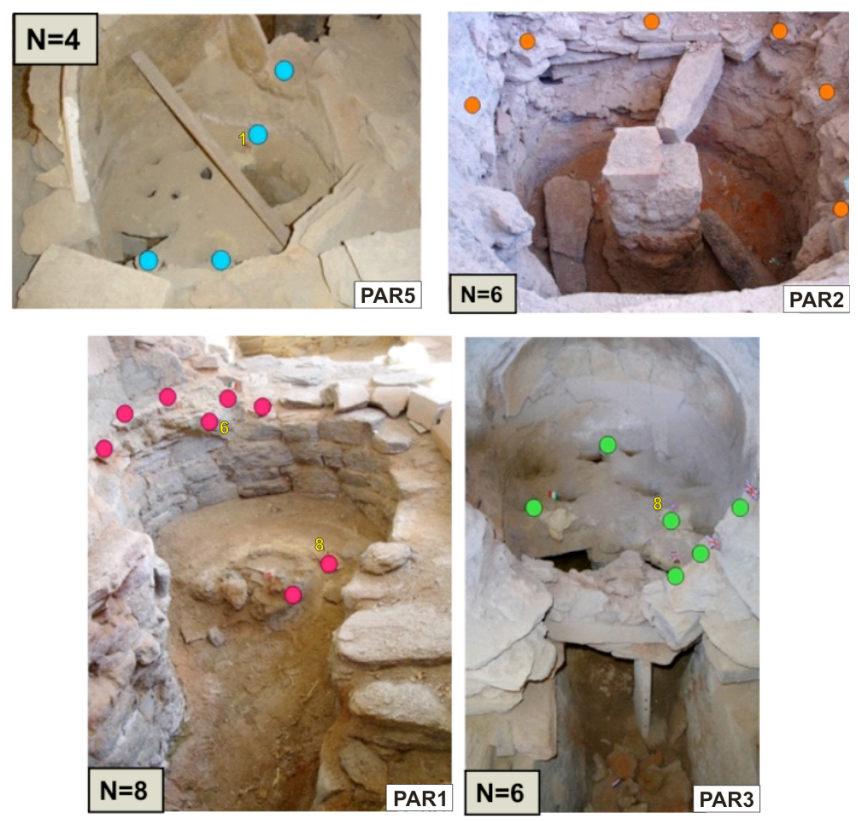

Figure 1. Kilns and sample distribution for the studied sites; $\mathrm{N}$ denotes the total number of samples collected from each feature. Samples used in archaeometric analyses (Tables 3 and 4) are noted with yellow numbers (photographs from De Marco 2007; V. Spatharas, personal communication).

Table 1. Geographical and chronological information for the studied sites.

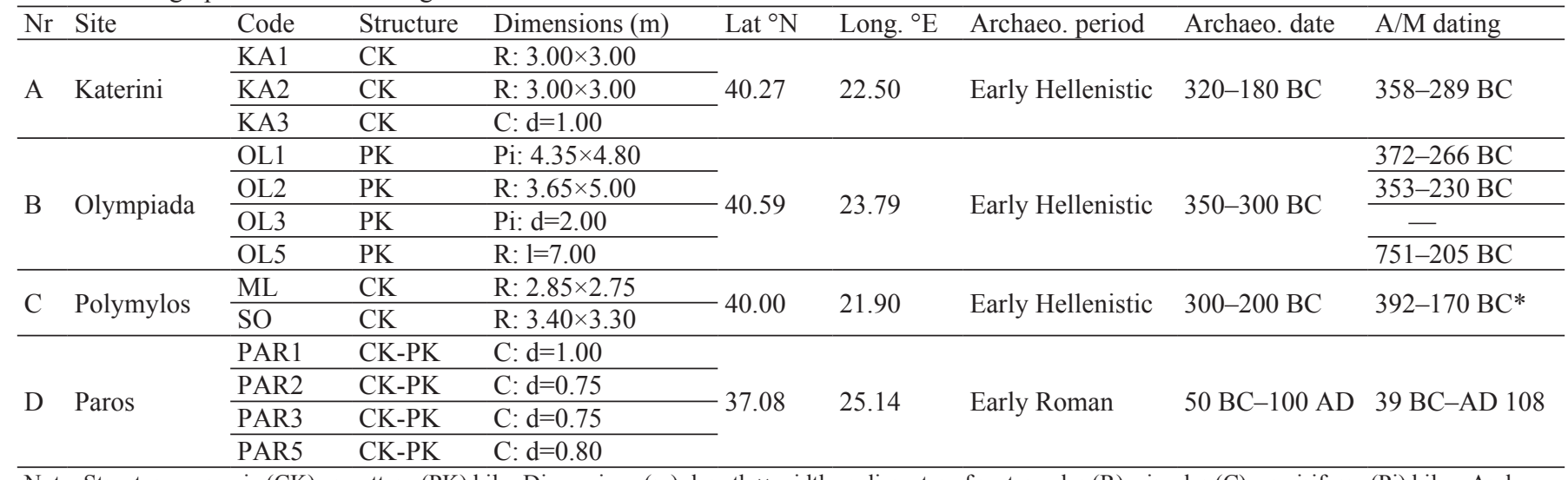

Note: Structure: ceramic (CK) or pottery (PK) kiln; Dimensions (m): length $\times$ width or diameter of rectangular (R), circular (C), or piriform (Pi) kilns; Archaeo. date: absolute date based on archaeological constraints; A/M dating: absolute date derived from archaeomagnetic dating using the Pavón-Carrasco et al. (2009) model [*: Aidona et al. (2010)]. 
Table 2. Directional and paleointensity results obtained from the studied sites.

\begin{tabular}{|c|c|c|c|c|c|c|c|c|c|}
\hline \multirow[b]{2}{*}{ Site } & \multicolumn{5}{|c|}{ Direction } & \multicolumn{3}{|c|}{ Intensity } & \multirow[b]{2}{*}{ Reference } \\
\hline & $\mathrm{D}\left({ }^{\circ}\right)$ & $\mathrm{I}\left({ }^{\circ}\right)$ & $\mathrm{N} / \mathrm{N}_{\mathrm{o}}$ & $\alpha_{95}$ & $\mathrm{k}$ & $\mathrm{F}(\mu \mathrm{T})$ & $\sigma(\mu \mathrm{T})$ & $\mathrm{N} / \mathrm{N}_{\mathrm{o}}$ & \\
\hline KA1 & 349.7 & 59.6 & $16 / 21$ & 2.8 & 176.0 & 85.8 & 7.8 & $5 / 6$ & \multirow{3}{*}{ DeMarco et al. 2008a, b } \\
\hline KA2 & 349.6 & 56.1 & $16 / 23$ & 4.8 & 59.2 & - & - & - & \\
\hline KA3 & 348.5 & 57.0 & $4 / 5$ & 12.8 & 52.2 & - & - & - & \\
\hline Katerini & 349.3 & 57.6 & $3 / 3$ & 2.8 & 1913.0 & 85.8 & 7.8 & $1 / 1$ & \\
\hline OL1 & 347.2 & 60.5 & $11 / 11$ & 4.1 & 126.4 & 72.8 & 8.0 & $5 / 5$ & \multirow{3}{*}{ De Marco 2007} \\
\hline OL2 & 343.5 & 66.6 & $7 / 9$ & 3.6 & 117.8 & 70.7 & 6.0 & $4 / 5$ & \\
\hline OL3 & \multicolumn{5}{|c|}{ unsuccessful } & - & - & - & \\
\hline OL5 & \multicolumn{5}{|c|}{ unsuccessful } & 70.8 & 6.5 & $7 / 11$ & \multirow{2}{*}{ Le Goff and Kondopoulou (unpublished data) } \\
\hline Olympiada & 345.5 & 63.6 & $2 / 2$ & 13.6 & 336.6 & 71.4 & 1.2 & $3 / 3$ & \\
\hline ML & \multirow{2}{*}{348.1} & \multirow{2}{*}{52.6} & \multirow{2}{*}{$14 / 16$} & \multirow{2}{*}{5.3} & \multirow{2}{*}{57.2} & 65.1 & 3.2 & $9 / 22$ & \multirow{2}{*}{ Aidona et al. 2010; Spatharas et al. 2011} \\
\hline $\mathrm{SO}$ & & & & & & 67.0 & 2.3 & $7 / 13$ & \\
\hline MA & \multicolumn{5}{|c|}{ unoriented material } & \multicolumn{3}{|c|}{ unsuccessful } & \multirow{3}{*}{ Spatharas 2005} \\
\hline CL5 & \multicolumn{5}{|c|}{ unoriented material } & \multicolumn{3}{|c|}{ unsuccessful } & \\
\hline Polymylos & 348.1 & 52.6 & $14 / 16$ & 5.3 & 57.2 & 66.0 & 2.2 & $2 / 2$ & \\
\hline PAR1 & 344.6 & 47.6 & $8 / 8$ & 2.7 & 427.8 & 57.6 & 5.0 & $8 / 8$ & \multirow{2}{*}{ De Marco 2007} \\
\hline \multirow{2}{*}{ PAR2 } & 21.3 & 56.2 & $3 / 6$ & 28.1 & 23.7 & - & - & - & \\
\hline & - & - & - & - & - & 51.2 & 4.6 & $5 / 8$ & \multirow{4}{*}{ Le Goff and Kondopoulou (unpublished data) } \\
\hline PAR3 & \multicolumn{5}{|c|}{ unsuccessful } & $50.9 *$ & 3.0 & $3 / 7$ & \\
\hline PAR5 & \multicolumn{5}{|c|}{ unsuccessful } & \multicolumn{3}{|c|}{ unsuccessful } & \\
\hline PRC & \multicolumn{5}{|c|}{ unoriented material } & 55.5 & 4.5 & $4 / 4$ & \\
\hline PR & \multicolumn{5}{|c|}{ unoriented material } & $65.9^{*}$ & 7.3 & $8 / 8$ & Tema et al. 2012 \\
\hline Paros & 344.6 & 47.6 & $1 / 2$ & 2.7 & 427.8 & 54.8 & 3.3 & $3 / 5$ & \\
\hline
\end{tabular}

Note: Mean remanence directions are given as declination (D), inclination (I), radius of $95 \%$ confidence $\left(\alpha_{95}\right)$, and precision parameter (k) (Fisher 1953). $\mathrm{N}_{0}$, the number of samples measured per group; $\mathrm{N}$, the number of samples used in calculation of mean remanence directions. Mean intensity (F) is accompanied with the corresponding standard error $(\sigma)$. Asterisk $(*)$ denotes result not used for the calculation of mean value.

\section{ARCHAEOMAGNETIC STUDY}

Several measurements were carried out in order to study the rock-magnetic properties of the archaeological materials as well as direction and intensity of the Earth's magnetic field recorded at each site. All relevant information can be retrieved from Spatharas (2005), De Marco (2007), and De Marco et al. (2008a, b).

The laboratory analyses comprised measurements of the natural remanent magnetization (NRM) the magnetic susceptibility (K) and its anisotropy, rock-magnetic experiments, magnetic cleaning for directional analysis, and archaeointensity studies. Apart from the already published results (Spatharas 2005; De Marco 2008a, b; Aidona et al. 2010; Spatharas et al. 2011; Tema et al. 2012), additional thermomagnetic analysis and Triaxe experiments (Le Goff and Gallet 2004) were carried out to complement the existing data set.

An important step towards understanding and evaluating the material's suitability for an archaeomagnetic study is the detailed examination of its magnetic properties and magnetic mineralogy. Results from representative samples are shown in Figure S2 and
Table 3. From the experiments conducted, the majority of samples proved to be suitable for the archaeomagnetic study, fulfilling two prerequisites: the Koenisberger ratio $(\mathrm{Q})$ values, measured on 435 samples, mostly lie in the $5<\mathrm{Q}<80$ interval, and are characteristic for a stable (thermoremanent) origin of the NRM. The magnetic viscosity coefficient, $S_{v}$, was calculated after storing the samples in a field-free space for 3 weeks, following Jordanova et al. (2003). Obtained values $\mathrm{S}_{\mathrm{v}}<6 \%$ indicate sufficient heating of the material. When plotting NRM versus $\mathrm{K}$ values, it is seen that specimens presenting lower NRM and $\mathrm{K}$ values generally correspond to less heated materials, mostly baked clays (De Marco 2007).

Magnetic properties vary with direction because it is easier for mineral phases to become magnetized along one axis than another. The anisotropy of magnetic susceptibility (AMS) and the one of remanence have been extensively studied in archaeological ceramic materials (Veitch et al. 1984; Stephenson et al. 1986) and their impact to the possible deflection of the remanence direction has been monitored. AMS was measured for the whole collection of samples; in general, the samples were not particularly anisotropic. Only in a few cases did P values exceed $10 \%$, most often in Paros with a mean value around $22 \%$. This high value can be 
Table 3. Archaeometric results of analyzed Hellenistic/Early Roman ceramic materials.

\begin{tabular}{|c|c|c|c|c|c|c|c|}
\hline Sample & $\begin{array}{l}\text { Intensity } \\
\text { (Thellier) }\end{array}$ & $\mathrm{He}$ & Mgt & $\mathrm{Sp}$ & $\begin{array}{l}\text { Estimated firing temp }\left({ }^{\circ} \mathrm{C}\right) \text {, } \\
\text { atmospheric conditions }\end{array}$ & $\begin{array}{l}\text { Color of ceramic body } \\
\text { (Munsell soil color chart) }\end{array}$ & $\begin{array}{l}\text { Sample } \\
\text { description }\end{array}$ \\
\hline KA1-4 & Successful & $\mathrm{Nd}$ & $\mathrm{Nd}$ & $1.34^{*}$ & $400-450^{\circ} \mathrm{C}$, ox atm & 5/6 strong brown $7.5 \mathrm{YR}$ & Brick/tile \\
\hline KA1-6 & - & $\mathrm{Nd}$ & $<1$ & 5.0 & $850-900^{\circ} \mathrm{C}, \mathrm{rd} \mathrm{atm}$ & $5 / 2$ grayish brown $2.5 \mathrm{Y}$ & Brick \\
\hline KA2-4 & - & $\mathrm{Nd}$ & $\mathrm{Nd}$ & & $700-750^{\circ} \mathrm{C}$ & $5 / 8$ strong brown $7.5 \mathrm{YR}$ & Tile \\
\hline KA3-2 & - & $\mathrm{Nd}$ & 1.4 & & $700-750^{\circ} \mathrm{C}, \mathrm{rd} \mathrm{atm}$ & $6 / 4$ light yellowish brown $10 \mathrm{YR}$ & Brick \\
\hline OL1-3b & Failed & $\mathrm{Nd}$ & $\mathrm{Nd}$ & & $400-450^{\circ} \mathrm{C}$ & $5 / 6$ yellowish red $5 \mathrm{YR}$ & Baked clay \\
\hline OL1-4c & Successful & 3.0 & $<1$ & 10.4 & $1000-1050^{\circ} \mathrm{C}$, ox atm & $4 / 4$ reddish brown $5 \mathrm{YR}$ & Baked clay \\
\hline OL2-2 & Successful & $\mathrm{Nd}$ & $\mathrm{Nd}$ & $1.2 * *$ & $600-650^{\circ} \mathrm{C}$, ox atm & $6 / 6$ reddish yellow $7.5 \mathrm{YR}$ & Brick \\
\hline OL3-7b & - & nd & $\mathrm{Nd}$ & & $600-650^{\circ} \mathrm{C}$ & $6 / 6$ reddish yellow $7.5 \mathrm{YR}$ & Baked clay \\
\hline OL5-7 & Successful \& T & 1.6 & $<1$ & 7.8 & $950-1000^{\circ} \mathrm{C}$, ox atm & $5 / 6$ strong brown $7.5 \mathrm{YR}$ & Baked clay \\
\hline ML1 & Successful & $<1$ & 2.5 & & $650-700^{\circ} \mathrm{C}, \mathrm{rd}$ atm & $5 / 6$ strong brown $7.5 \mathrm{YR}$ & Baked clay/tile \\
\hline ML2 & Successful & 2.6 & $\mathrm{Nd}$ & & $750-800^{\circ} \mathrm{C}$, ox atm & $5 / 6$ red $2.5 \mathrm{YR}$ & Baked clay/tile \\
\hline ML5-5 & Failed & $<1$ & $\mathrm{Nd}$ & & $750-800^{\circ} \mathrm{C}$, ox atm & $5 / 8$ red $2.5 \mathrm{YR}$ & Baked clay/tile \\
\hline ML6 & Successful & 2.2 & $\mathrm{Nd}$ & 2.5 & $750-800^{\circ} \mathrm{C}$, ox atm, & $5 / 6$ red $2.5 \mathrm{YR}$ & Baked clay/tile \\
\hline ML7 & Successful & 2.7 & $\mathrm{Nd}$ & & $750-800^{\circ} \mathrm{C}$, ox atm & $5 / 6$ red $2.5 \mathrm{YR}$ & Baked clay/tile \\
\hline SO1 & Successful & $\mathrm{Nd}$ & 2.3 & & $800-850^{\circ} \mathrm{C}, \mathrm{rd} \mathrm{atm}$ & $5 / 8$ strong brown $7.5 \mathrm{YR}$ & Baked clay/tile \\
\hline $\mathrm{SO} 2-3 \mathrm{a}$ & Successful & 3.0 & $\mathrm{Nd}$ & 7.2 & $800-850^{\circ} \mathrm{C}$, ox atm & $5 / 6$ yellowish red $5 \mathrm{YR}$ & Baked clay/tile \\
\hline SO3-5a & Failed & 6.8 & 1.0 & 8.8 & $800-850^{\circ} \mathrm{C}$, ox atm & $5 / 6$ red $10 Y R$ & Baked clay/tile \\
\hline $\mathrm{SO} 4$ & Successful & 4.9 & $\mathrm{Nd}$ & & $750-800^{\circ} \mathrm{C}$, ox atm & $4 / 6 \mathrm{red} 2.5 \mathrm{YR}$ & Baked clay/tile \\
\hline $\mathrm{SO} 5$ & Successful & 3.5 & $\mathrm{Nd}$ & 3.1 & $750-800^{\circ} \mathrm{C}$, ox atm & $5 / 6$ red $2.5 \mathrm{YR}$ & Baked clay/tile \\
\hline SO7-4 & Successful & $\mathrm{Nd}$ & 1.0 & & $550-600^{\circ} \mathrm{C}, \mathrm{rd} \mathrm{atm}$ & 6/4 light brown $7.5 \mathrm{YR}$ & Baked clay/tile \\
\hline SO8-Ia & - & $\mathrm{Nd}$ & $\mathrm{Nd}$ & & $600-650^{\circ} \mathrm{C}$ & $5 / 6$ yellowish red $5 \mathrm{YR}$ & Baked clay/tile \\
\hline PAR1-6 & Successful & $\mathrm{Nd}$ & 1.3 & & $650-700^{\circ} \mathrm{C}, \mathrm{rd} \mathrm{atm}$ & $6 / 2$ light brownish gray $10 \mathrm{YR}$ & Baked clay \\
\hline PAR1-8 & Successful & $<1$ & 1.1 & 1.5 & $1050-1100^{\circ} \mathrm{C}, \mathrm{rd} \mathrm{atm}$ & $7 / 2$ light gray $10 \mathrm{YR}$ & Baked clay \\
\hline PAR3-6b & Failed \& T & 2.8 & $\mathrm{Nd}$ & & $800-850^{\circ} \mathrm{C}$, ox atm & $6 / 6$ reddish yellow $7.5 \mathrm{YR}$ & Tile \\
\hline PAR5-1b & Successful \& T & 1.0 & $\mathrm{Nd}$ & & $850-900^{\circ} \mathrm{C}$, ox atm & 6/4 light brown $7.5 \mathrm{YR}$ & Baked clay \\
\hline
\end{tabular}

Note: Second column: archaeointensity results, T denotes additional successful results from Triaxe experiments; third to fifth columns: Rietveld-based quantification analysis of their ceramic body [wt \% of the Fe oxides, He: hematite, Mgt: magnetite, and Sp: spinels (i.e. spinel, hercynite, titanomagnetite*, magnesioferrite**), Nd: not detected (not existing or quantity below the detection limits)]; sixth column: estimated firing conditions (ox: oxidizing, rd: reducing atmosphere); seventh column: macroscopic observation of ceramic "body" color; eighth column: type of ceramic material.

explained by the use of tiles and bricks in Paros kilns because the moulding process during their manufacture can result in a deflection of the magnetization. The shape of the anisotropy ellipsoid, calculated for all samples originating from kilns, was oblate (shape factor $\mathrm{T}>0$ ), and magnetic grains were oriented parallel to horizontal surfaces of the structure. To avoid significant error upon the estimated paleointensities, all the obtained results were corrected for anisotropy in accordance with the technique developed by Veitch et al. (1984).

\section{Archaeodirections}

The removal of eventual secondary magnetization components is essential for a reliable archaeomagnetic result. Both thermal and alternating field (AF) demagnetization techniques were employed for this purpose using an MMTD1 thermal demagnetizer or a custom field-free space furnace and a Molspin Ltd. tumbling AF demagnetizer. Each specimen was subjected to 11-14 demagnetization steps up to either a maximum temperature of $680^{\circ} \mathrm{C}$ or a peak field of $100 \mathrm{mT}$. Characteristic components of magnetization were found from orthogonal vector plots and principal component analysis (PCA; Kirschvink 1980), whereas site mean remanence directions were computed using Fisherian statistics (Fisher 1953). The mean calculated directions and their statistics are presented in Table 2 and their stereographic projection in Figure 2.

\section{Archaeointensity}

In order to obtain a full archaeomagnetic record for the studied archaeological sites, archaeointensity measurements were performed (Table 2 and references therein). These results were obtained through two different experimental procedures:

a. Archaeointensity measurements following the Thellier method (Thellier and Thellier 1959). After laboratory analyses, the archaeointensity was calculated from the slope of the linear part of the NRM-TRM plot (Figure S3), using the least-squares fitting analysis of Coe et al. (1978). The applied criteria for the acceptance or rejection of the results are those described by Chauvin et al. (2000) and Gómez-Paccard et al. (2006). The mean archaeointensity for each site was determined using the weighting factor described by Prévot et al. (1985) and the corresponding uncertainty about the mean is expressed by the standard deviation of the unweighted average (Table 2). 

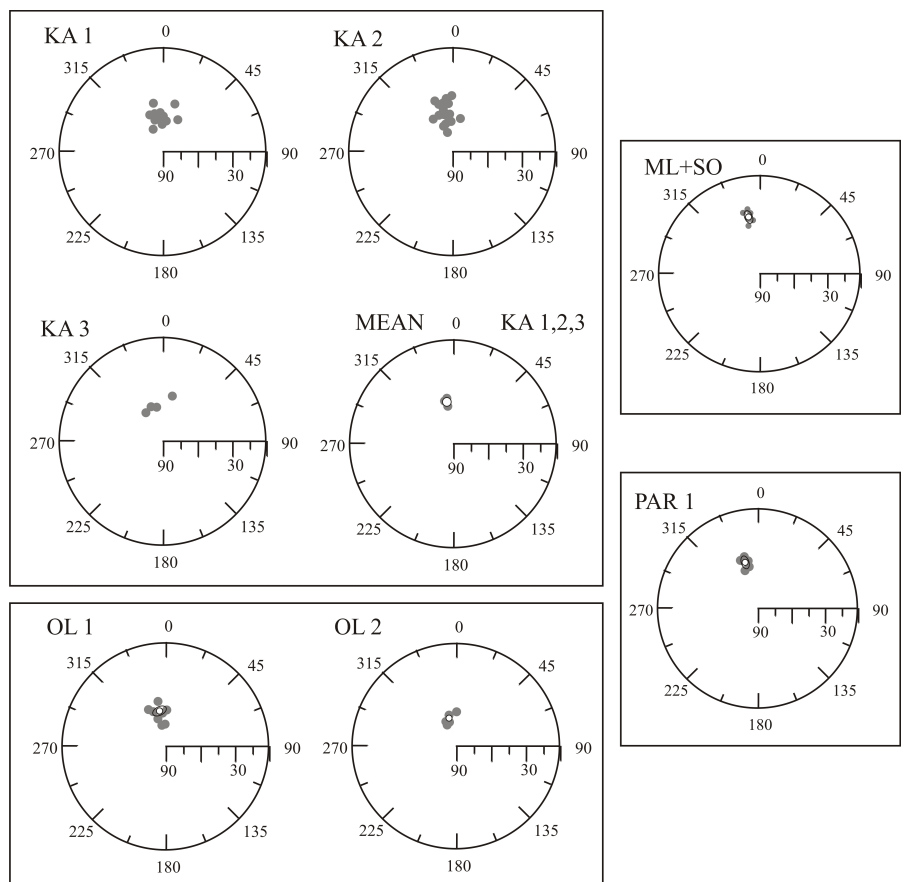

Figure 2. Lower hemisphere stereographic projection of the ChRM directions at the sample level (gray symbols), together with the mean direction and their $\alpha 95$ semicone of confidence (white circles and ellipses), for each of the studied kilns. For the site of Katerini, the three kilns are shown separately, together with the resultant mean for the site.

b. Archaeointensity experiments following the Triaxe protocol (Le Goff and Gallet 2004) in St. Maur, France (unpublished data from Le Goff and Kondopoulou). In these experiments, material from kilns OL5, PAR2, PAR3, and PAR5, as well as from Paros intraworkshop ceramics, was used. The technique, designed to perform automated high-temperature magnetization measurements on small cylindrical specimens $<1 \mathrm{~cm}^{3}$ in volume, involves several continuous zero-field heating and cooling cycles up to a maximum temperature of $550^{\circ} \mathrm{C}$ with a rate of $25^{\circ} \mathrm{C} / \mathrm{min}$ and one in-field cooling cycle. Magnetization was monitored through all cycles with a three-axis vibrating sample magnetometer within a Helmholtz coil system covered by a $\mu$-metal shield. It has to be noted that anisotropy of TRM is automatically corrected by correcting the field orientation in order to obtain remanent magnetization in the exact NRM direction. Archaeointensity is defined as the mean of parameter $R^{\prime}(T)$ over the temperature range used. Characteristic $R^{\prime}(T)$ curves from the studied ceramic samples are shown in Figure 3. The quality criteria applied in order to discriminate successful from unsuccessful experiments rely on the presence of a unidirectional NRM, a smooth shape of the R'(T) curve, a slope of $\mathrm{R}^{\prime}(\mathrm{T})$ that is lower than $15 \%$, and the fact that more than $50 \%$ of the NRM is involved in the calculation of archaeointensity. The obtained values for the studied kilns and ceramics, after severe selection, are presented below:

$\begin{array}{lll}\text { OL5 (kiln) } & \mathrm{N}=11 & \mathrm{~F}=70.8 \pm 6.5 \mu \mathrm{T} \\ \text { PAR 2 (kiln) } & \mathrm{N}=5 & \mathrm{~F}=51.2 \pm 4.6 \mu \mathrm{T} \\ \text { PAR 3 (kiln) } & \mathrm{N}=3 & \mathrm{~F}=50.8 \pm 3 \mu \mathrm{T} \\ \text { PAR5 (kiln) } & & \text { unsuccessful } \\ \text { PRC (ceramics) } & \mathrm{N}=4 & \mathrm{~F}=55.5 \pm 4.5 \mu \mathrm{T}\end{array}$

Recently, another set of intensity data were obtained from eight ceramic fragments from the Paros ceramic workshop, following the Thellier method (Tema et al. 2012). These new data give a different value of the archaeointensity $(\mathrm{N}=8, \mathrm{~F}=65.9 \pm 7.3 \mu \mathrm{T})$, by about $12 \mu \mathrm{T}$. As these data come from two different laboratories (Barcelona and Torino) but follow the same protocol, this value is double checked. An age difference between the two data sets cannot account for this apparent divergence because the lifetime of the workshop does not exceed 150 years and variations in geomagnetic field intensity for this period are quite smooth. According to Genevey et al. (2008), differences of this order are observed in data sets and, in the present case, the published mean of successful samples from Paros [PAR1 $(\mathrm{N}=8, \mathrm{~F}=57.6 \pm 5.0 \mu \mathrm{T})$, De Marco et al. 2008] lies within the grouping observed for the same ages. Averaging the results from the Triaxe (kilns PAR2, PAR3, and ceramic fragments PRC) and Thellier (kiln PAR1, and ceramic PR, Tema et al. 2012) experiments, we see that the above values converge well towards a mean of $56.2 \pm 5.7 \mu \mathrm{T}$, which lies within the expected value for this period, as derived by regional models.

\section{ESTIMATED FIRING CONDITIONS}

A set of 25 samples, mainly of baked clay and a few bricks and tiles collected from the four sites examined, has been subjected to mineralogical (XRPD) and petrographic (polarizing microscopy) analysis to establish their mineral and structural changes as a function of pyrometamorphism at $1 \mathrm{~atm}$ (see Appendix $\mathrm{C}$ for details of analytical methods; Figures 4 and S4). The main purpose is to assess their firing conditions (i.e. temperature, atmosphere, time) because the degree of thermal transformation to which the clay paste of ceramics has been subjected during firing procedure is largely affected by the prevailing conditions in the kiln. In this view, a ceramic made of a calcareous clay-paste $(\mathrm{CaO}>6 \% \mathrm{wt})$ and fired at $\geq 850^{\circ} \mathrm{C}$ in an oxidizing atmosphere is expected to have a specific mineralogical paragenesis consisting of neocrystallized high-T minerals (i.e. wollastonite, anorthite, gehlenite, diopside) - products of the reactions between the decomposed calcite, the dehydroxylated clay/phyllosilicate minerals and quartz grains (Nodari et al. 2007; Rathossi and Pontikes 2010a and references therein)—with the iron oxide content (hematite) low because of the incorporation of iron ions in the structure of neoformed Ca-Al-silicate phases (diopside, gehlenite) (Rathossi and Pontikes 2010b and references therein). The optical behavior of the ceramic micromass under the polarizing microscope is anticipated to be optically slightly active to inactive as the structural breakdown of clay minerals is complete and the sintering process has started (Whitbread 1995). Thus, by elucidating the mineralogical composition of the ceramic "body," such as the preservation of primary minerals (i.e. calcite, clay minerals) or/and the newly formed high-T crystalline phases (i.e. diopside, gehlenite, anorthite, wollastonite, enstatite, mullite, cristobalite, spinel, iron oxides) as well as the optical state of ceramic micromass, it is possible to estimate the firing temperature and the redox state of atmosphere, with respect to the hematitemagnetite buffer, under which the ceramic was produced. 


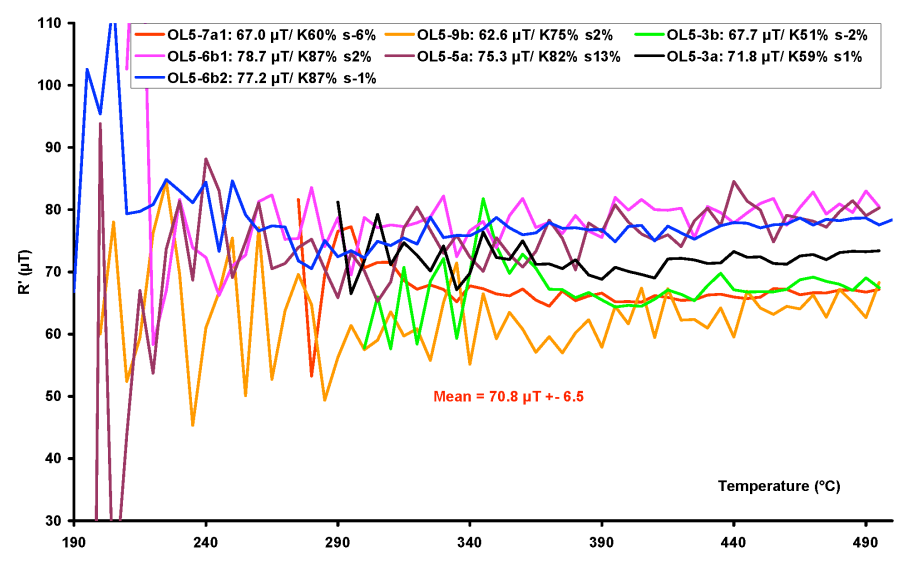

Figure 3. Successful archaeointensity determinations from several samples from Olympiada kiln OL5, applying the continuous high-temperature magnetization measurement method (Triaxe protocol). The paleointensity is defined as the mean of parameter $R^{\prime}(T)$ over the used temperature range and a successful experiment is indicated if $R^{\prime}(T)$ remains constant over the whole range.
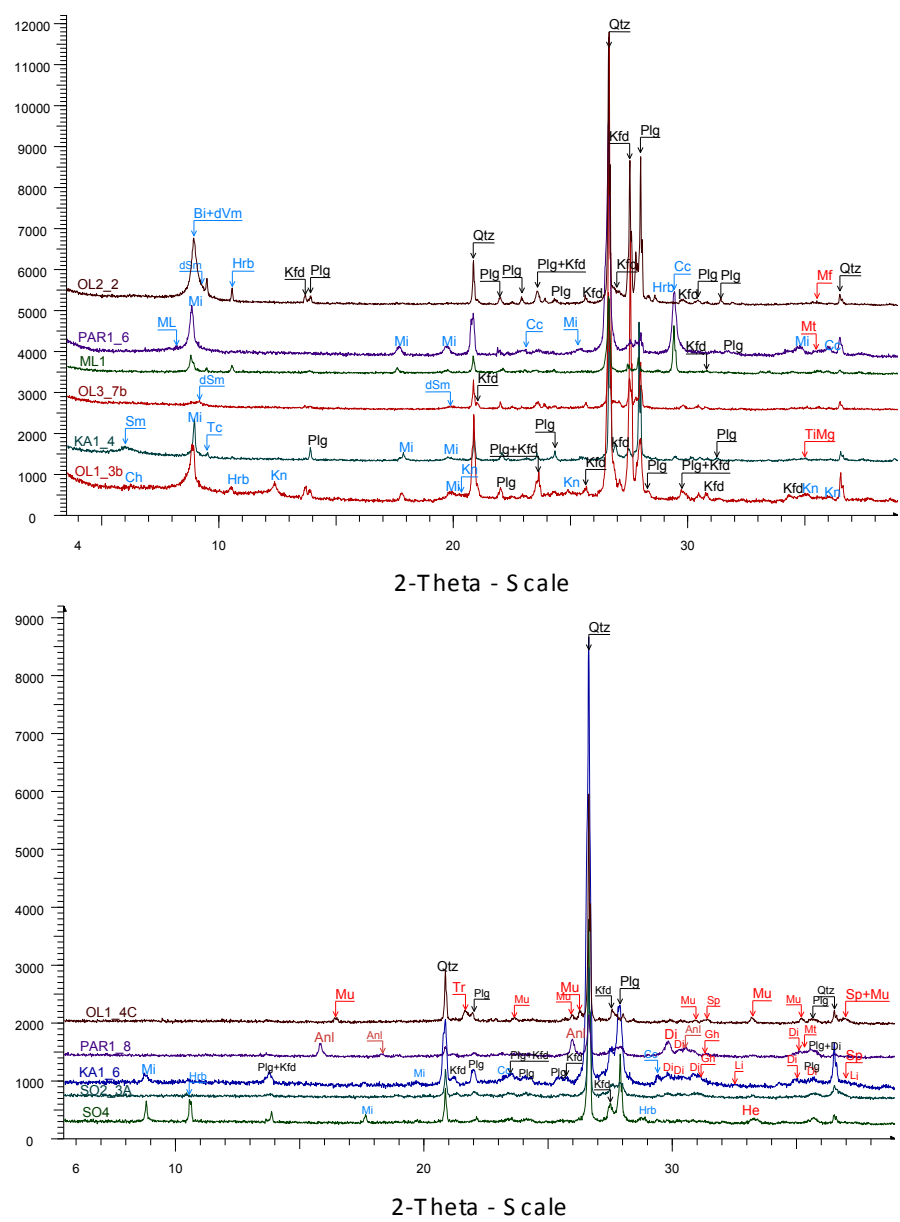

Figure 4. X-ray diffraction patterns of representative samples at various firing temperatures. The estimated firing temperature for each sample is given in Table 3. Abbreviations: $\mathrm{Qtz}=$ quartz; $\mathrm{Plg}=$ plagioclase; $\mathrm{Kfd}=\mathrm{k}$-feldspar; $\mathrm{Cc}=$ calcite; $\mathrm{Mi}=$ white mica; $\mathrm{Bi}=$ biotite $\mathrm{Ch}=$ chlorite; $\mathrm{Kn}=$ kaolinite; $\mathrm{Sm}=$ smectite; $\mathrm{dSm}=$ dehydrated smectite; $\mathrm{dVm}=$ dehydrated vermiculite; $\mathrm{Tc}=$ talc; $\mathrm{Hrb}=$ hornblende; $\mathrm{Li}=$ lime; $\mathrm{Di}=$ diopside; $\mathrm{Gh}=$ gehlenite; $\mathrm{Mu}=$ mullite; $\mathrm{Tr}=\beta$-tridymite; $\mathrm{Anl}=$ secondary analcime $; \mathrm{Sp}=$ spinel $; \mathrm{He}=$ hematite $\mathrm{Mt}=$ magnetite; $\mathrm{Mf}=$ magnesioferrite; $\mathrm{TiMg}=$ titanomagnetite.
In the presently studied kiln materials, it has to be noted, though, that by the term "firing temperature" we do not necessarily refer to the last firing of the material, because any subsequent firing at temperatures lower than the maximum temperature reached will not affect the material that had been previously heated to that high temperature.

The X-ray powder diffraction (XRPD) data from the Hellenistic and Early Roman studied ceramics reveal either the preservation of primary minerals, such as clay minerals, mica, calcite, and hornblende, representative of the type of their raw materials (Appendix B), or the crystallization of new high-T mineral phases (i.e. diopside, gehlenite, mullite, tridymite) during the pyrometamorphic process (Figure 4). The latter develops upon reactions that occur between the decomposed primary minerals as the firing temperature rises and the sintering advances. The petrographic fabric of the ceramic micromass ranges from active (highly birefringent caused by the preservation of clay minerals) to inactive (because of the structural collapse of clays) (Whitbread 1995). Combining the data from both analytical methods, a wide range of firing temperatures and atmospheres has been established, as expected, within the same kiln (Table 3). This result clearly is dependent upon the structural position of the presently studied material inside the kilns as well as the dimensions of the kilns (Figure 1, Table 1) as suggested also by Morales et al. (2011). As mentioned above, all the places inside a kiln did not experience the same firing conditions; in conjunction with the fact that the time operation of the kiln is commonly long, its structural materials will have suffered the effects of repeated firing processes. Thus, the material that has been collected close to the entrance of a kiln exhibits lower temperatures than that extracted from the combustion chamber. The petrological characteristics of each sample, which determine their firing conditions, are the following:

\section{a. Katerini (kilns KA1, KA2, KA3): Estimated firing $400-900^{\circ} \mathrm{C}$}

The clay minerals smectite and illite in the ceramic body of sample KA1-4, which assign an optically highly active micromass under polarized-light microscopic observation, establish a very low firing temperature between 400 and $450^{\circ} \mathrm{C}$ (Figures 4 and S4) (Mackenzie 1957; Grim 1968). A higher firing, at 700 $750^{\circ} \mathrm{C}$, has been recorded by the structural breakdown of smectite and the small amount of undecomposed primary calcite (up to 3 wt\%) in samples KA2-4 and KA3-2 (Shoval et al. 1993; Murad and Wagner 1998). In contrast, for sample KA1-6 its optically inactive micromass, the preservation of white mica (illite/muscovite) and the neocrystallization of high-T minerals, such as clinopyroxene (diopside, $11.9 \mathrm{wt} \%$ ), melilite (gehlenite, $2.4 \mathrm{wt} \%$ ), and hercynite spinel $(5.0 \mathrm{wt} \%)$, indicates a higher temperature, $850-900^{\circ} \mathrm{C}$ (Figure 4) (Rathossi and Pontikes 2010a).

The results of the Rietveld quantitative mineral analysis showed small amounts of magnetite $(1.4 \mathrm{wt} \%)$ and titanomagnetite $(1.3 \mathrm{wt} \%)$ only in two samples. As these magnetic minerals provide information about the atmospheric conditions during the 
Table 4. Magnetization parameters of the samples used for archaeometric analyses.

\begin{tabular}{|c|c|c|c|c|c|c|}
\hline Sample & $\begin{array}{l}\text { Temp. firing } \\
\left({ }^{\circ} \mathrm{C}\right)\end{array}$ & $\begin{array}{l}\text { MAG } \\
(\mathrm{A} / \mathrm{m})\end{array}$ & $\begin{array}{l}\mathrm{K} \\
\left(\times 10^{-5} \mathrm{SI}\right)\end{array}$ & Q & $\mathrm{S}_{\mathrm{v}}$ & Mat. \\
\hline KA1-4a & $400-450$ & $3.75 \mathrm{E}+00$ & 257.0 & 39.9 & - & $\mathrm{BR}$ \\
\hline $\mathrm{KA} 1-4 \mathrm{~b}$ & & $5.80 \mathrm{E}+00$ & 393.0 & 40.3 & - & $\mathrm{BR}$ \\
\hline $\mathrm{KA} 1-4 \mathrm{c}$ & & $1.70 \mathrm{E}+01$ & - & - & - & BR \\
\hline $\mathrm{KA} 1-4 \mathrm{~d}$ & & $1.47 \mathrm{E}+01$ & - & - & - & TL \\
\hline KA1-6a & $850-900$ & $2.32 \mathrm{E}+00$ & 190.8 & 31.6 & - & $\mathrm{BR}$ \\
\hline KA1-6b & & $4.20 \mathrm{E}+00$ & 306.0 & 40.1 & - & $\mathrm{BR}$ \\
\hline KA2-4a & $700-750$ & $5.26 \mathrm{E}-01$ & 139.0 & 10.3 & - & TL \\
\hline KA2-4b & & $5.43 \mathrm{E}-01$ & 145.0 & 10.3 & - & $\mathrm{TL}$ \\
\hline KA2-4c & & $5.48 \mathrm{E}-01$ & 169.0 & 8.9 & - & TL \\
\hline KA3-2a & $700-750$ & $1.81 \mathrm{E}+00$ & 363.0 & 13.6 & - & $\mathrm{BR}$ \\
\hline KA3-2b & & $2.20 \mathrm{E}+00$ & 398.8 & 15.0 & - & $\mathrm{BR}$ \\
\hline KA3-2c & & $1.77 \mathrm{E}+00$ & 376.3 & 12.9 & - & $\mathrm{BR}$ \\
\hline OL1-3a & $400-450$ & $1.03 \mathrm{E}+00$ & 449.5 & 6.3 & 2.8 & $\mathrm{BC}$ \\
\hline OL1-3b & & $1.55 \mathrm{E}+01$ & 118.2 & 3.6 & 5.5 & $\mathrm{BC}$ \\
\hline OL1-4a & $1000-1050$ & $6.86 \mathrm{E}+00$ & 259.0 & 72.4 & 1.7 & $\mathrm{BC}$ \\
\hline $\mathrm{OL} 1-4 \mathrm{a}_{23}$ & & $6.42 \mathrm{E}+00$ & 35.5 & 5.5 & 2.0 & $\mathrm{BC}$ \\
\hline OL $1-4 b^{2,3}$ & & $6.13 \mathrm{E}+00$ & 353.6 & 47.4 & 3.5 & $\mathrm{BC}$ \\
\hline OL1-4c & & $6.98 \mathrm{E}+00$ & 238.0 & 80.2 & 3.1 & $\mathrm{BC}$ \\
\hline OL1-4d & & $2.76 \mathrm{E}+00$ & 114.0 & 66.1 & 3.1 & $\mathrm{BC}$ \\
\hline OL2-2a & $600-650$ & $2.85 \mathrm{E}+00$ & 335.0 & 22.0 & 2.2 & $\mathrm{BR}$ \\
\hline OL $2-2 b$ & & $2.35 \mathrm{E}+00$ & 279.0 & 25.0 & 4.3 & $\mathrm{BR}$ \\
\hline OL2-2c & & $1.01 \mathrm{E}+00$ & 144.0 & 19.2 & 5.1 & $\mathrm{BR}$ \\
\hline OL2-2d & & $9.65 \mathrm{E}-01$ & 121.0 & 21.8 & 3.4 & $\mathrm{BR}$ \\
\hline OL3-7a & $600-650$ & $7.70 \mathrm{E}-02$ & - & - & - & $\mathrm{BC}$ \\
\hline OL3-7b & & $9.24 \mathrm{E}-02$ & - & - & - & $\mathrm{BC}$ \\
\hline OL3-7c & & $4.94 \mathrm{E}-02$ & - & - & - & $\mathrm{BC}$ \\
\hline$\overline{O L 5-7 a}$ & $950-1000$ & $5.04 \mathrm{E}+00$ & - & - & - & $\mathrm{BC}$ \\
\hline OL5-7b & & $4.73 \mathrm{E}+00$ & - & - & - & $\mathrm{BC}$ \\
\hline OL5-7c & & $1.67 \mathrm{E}+00$ & - & - & - & $\mathrm{BC}$ \\
\hline$\overline{\text { ML1 }}$ & $650-700$ & $3.77 \mathrm{E}+00$ & 736.0 & - & - & $\mathrm{BC}$ \\
\hline ML2 & $750-800$ & $2.21 \mathrm{E}+00$ & 266.0 & - & - & $\mathrm{BC}$ \\
\hline ML5-5 & $750-800$ & $0.275 \mathrm{E}+00$ & 55.0 & - & - & $\mathrm{BC}$ \\
\hline ML6 & $750-800$ & $0.439 \mathrm{E}+00$ & 74.0 & - & - & $\mathrm{BC}$ \\
\hline ML7 & $750-800$ & $0.280 \mathrm{E}+00$ & 52.0 & - & - & $\mathrm{BC}$ \\
\hline$\overline{\mathrm{SO} 1}$ & $800-850$ & $3.02 \mathrm{E}+00$ & 775.0 & - & - & $\mathrm{BC}$ \\
\hline $\mathrm{SO} 2-3 \mathrm{a}$ & $800-850$ & $0.442 \mathrm{E}+00$ & 967.0 & - & - & $\mathrm{BC}$ \\
\hline SO3-5a & $800-850$ & $0.41 \mathrm{E}+00$ & 285.0 & - & - & $\mathrm{BC}$ \\
\hline $\mathrm{SO} 4$ & $750-800$ & & - & - & - & $\mathrm{BC}$ \\
\hline SO5 & $750-800$ & $0.37 \mathrm{E}+00$ & 102.0 & - & - & $\mathrm{BC}$ \\
\hline $\mathrm{SO} 7-4$ & $550-600$ & $5.28 \mathrm{E}+00$ & 933.0 & - & - & $\mathrm{BC}$ \\
\hline SO8-1a & $650-700$ & $2.35 \mathrm{E}+00$ & 441.0 & - & - & $\mathrm{BC}$ \\
\hline \multirow[t]{3}{*}{$\overline{\text { PAR1-6a }}$} & $650-750$ & $6.02 \mathrm{E}+00$ & 1528.0 & 10.0 & 1.3 & $\mathrm{BC}$ \\
\hline & & $5.12 \mathrm{E}+00$ & 1125.0 & 10.3 & 4.3 & $\mathrm{BC}$ \\
\hline & & $6.08 \mathrm{E}+00$ & 1684.0 & 9.0 & 2.8 & $\mathrm{BC}$ \\
\hline PAR1-8(a,d) & $1050-1100$ & $3.02 \mathrm{E}+00$ & 657.5 & 10.0 & 3.6 & $\mathrm{BC}$ \\
\hline PAR3-6b & $800-850$ & $9.02 \mathrm{E}+00$ & 2256.0 & 11.0 & 4.3 & TL \\
\hline PAR5-1b & $850-900$ & $1.70 \mathrm{E}+00$ & 366.0 & 12.7 & 5.1 & $\mathrm{BC}$ \\
\hline
\end{tabular}

Note: Temp. firing: firing temperature estimated from archaeometric experiments (Table 3); K: bulk low-field magnetic susceptibility; Q: Koenisberger ratio $\left(\mathrm{Q}=\mathrm{MAG} /(\mathrm{K} \times \mathrm{H})\right.$, where $\mathrm{H} \approx 46 \mu \mathrm{T}$ for Greece); $\mathrm{S}_{\mathrm{v}}$ : viscosity coefficient $\left(\mathrm{S}_{\mathrm{v}}=\right.$ $\left.\left[\left(\mathrm{NRM}_{0}-\mathrm{NRM}_{\mathrm{ST}}\right) / \mathrm{NRM}_{0}\right] \times 100\right)$; Mat. (material): baked clay (BC), brick (BR), or tile (TL). firing cycle, it is concluded that samples KA1-6 and KA3-2 have been fired under a reducing atmosphere because the presence of magnetite indicates that the system was at the $\mathrm{Fe}_{3} \mathrm{O}_{4}$ stability field of the hematite-magnetite (HM) buffer whereas the presence of titanomagnetite in KA1-4 establishes oxidizing firing (Table 4) (Spear 1995).

\section{b. Olympiada (kilns OL1, OL2, OL3, OL5): Estimated firing ${ }^{400}-1050^{\circ} \mathrm{C}$}

During the petrographic analysis, most of the ceramic samples exhibit an optically highly active micromass caused by the preservation of clay minerals because they have been subjected to low firing temperature. Specifically, the detection of kaolinite in sample OL1-3b is the index for elucidating its low firing temperature, $400-450^{\circ} \mathrm{C}$ (Figure 4) (Mackenzie 1957; Grim 1968). On the other hand, for samples OL2-2 and OL3-7b the reflections of the dehydrated vermiculite and smectite and their optically highly active micromass show firing to a peak temperature of $600-650^{\circ} \mathrm{C}$ (Figures 4 and S4). The samples OL5-7 and OL1-4c seem to have been fired at high temperature $\geq 950^{\circ} \mathrm{C}$, as estimated by the formation of mullite ( 8.3 to $18 \mathrm{wt} \%), \beta$-tridymite ( $4.9 \mathrm{wt} \%$ ), and spinel (7.8 to $10.4 \mathrm{wt} \%$ ) (Figure 4 ) produced by the decomposition of clay minerals and their optically highly inactive micromass (isotropic) (Mackenzie 1957; Murad and Wagner 1998).

Regarding the presence of iron oxides, hematite (up to $3 \mathrm{wt} \%$ ) is present in the highly fired samples OL5-7 and OL1-4c together with a very low amount of magnetite $(<1 \mathrm{wt} \%)$, while magnesioferrite spinel $(1.2 \mathrm{wt} \%)$ has been detected in sample OL2-2 (Table 3). These iron oxides are indices for a prevailing mild oxidizing to oxidizing atmosphere during the firing process.

\section{c. Polymylos (SO, ML): Estimated firing $550-850^{\circ} \mathrm{C}$}

For samples ML1, SO7-4, and SO8-1a, the existence of the primary minerals chlorite, dehydrated smectite, talc, and calcite suggests that they were submitted to firing at a low temperature, spanning from 550 to $700^{\circ} \mathrm{C}$ (Figure 4). Samples ML2, ML5-5, ML6, ML7, SO4, and SO5 could have been fired at $750-800^{\circ} \mathrm{C}$ because the primary mica (i.e. muscovite, biotite) and hornblende are still present but the decarbonation of calcite and the dehydroxylation of chlorite and smectite have been completed. This leads to the start of mineral transformation in some of the samples as evidenced by the low gehlenite content (up to $2.0 \mathrm{wt} \%$ ) and their optically slightly active micromass (Figures 4 and S4).

In the case of samples $\mathrm{SO} 1, \mathrm{SO} 2-3 \mathrm{~A}$, and $\mathrm{SO}-5 \mathrm{~A}$, the structure of mica and hornblende has been destroyed and the quantity of newly formed diopside, gehlenite (up to $7.0 \mathrm{wt} \%$ ), and spinel $(8.8 \mathrm{wt} \%)$ is enhanced. These data are considered as diagnostic of a higher firing temperature $800-850^{\circ} \mathrm{C}$ (Figure 4). Concerning the magnetic minerals, hematite (up to $6.8 \mathrm{wt} \%$, Table 3 ) is predominant and has been detected in the majority of analyzed samples, reinforcing the hypothesis inferred by the red sherds, that the firing was conducted in a strong oxidizing atmosphere or 
mildly oxidizing when associated with magnetite. Magnetite exists in smaller quantities up to $2.3 \mathrm{wt} \%$ and has been determined to be present in 3 out of 12 samples (Table 3 ).

\section{d. Paros (kilns PAR1, PAR3, PAR5): Estimated firing 650- $1100^{\circ} \mathrm{C}$}

The detection of calcite, white mica, and a mixed layer of clay mineral reveals that the maximum firing temperature of sample PAR1-6 was $650-700^{\circ} \mathrm{C}$ (Figures 4 and S4). For sample PAR3$6 \mathrm{~b}$, the crystallization of $\mathrm{Ca}-\mathrm{Al}$ silicates, gehlenite $(3.7 \mathrm{wt} \%)$, and diopside (1.4 wt $\%$ ) implies that the firing temperature could not have exceeded $800-850^{\circ} \mathrm{C}$, whereas for PAR5-1b, the higher content of gehlenite $(18.2 \mathrm{wt} \%)$ and diopside $(12.6 \mathrm{wt} \%)$ indicate a firing temperature around $850-900^{\circ} \mathrm{C}$. The deducible high firing at $1050-1100^{\circ} \mathrm{C}$ for sample PAR1-8 is supported by the considerable amount of neoformed diopside $(39.3 \mathrm{wt} \%)$ in combination with the presence of the secondary analcime (12.4 wt $\%)$, which is the result of the alteration of the glassy phase during the postburial deposition processes (Schwedt et al. 2006) (Figure 4). The iron oxides, both hematite and magnetite, occur in relatively small amounts (up to $2.8 \mathrm{wt} \%$, Table 3 ). One reason for their low content is the outcome of the incorporation of Fe ions in the structure of diopside and gehlenite (Rathossi and Pontikes 2010b and references therein).

\section{DISCUSSION}

The mineralogical investigation determined that a wide range of firing temperatures from 500 up to $1000^{\circ} \mathrm{C}$ was recorded for ceramic material of the studied Hellenistic and Early Roman kilns (Figure 4, Table 3). However, the majority of samples from Katerini, Polymylos, and Paros have been fired at $>700^{\circ} \mathrm{C}$, making them suitable for archaeomagnetic research. Concerning the kilns of Olympiada, several lower temperatures have been obtained. It must be noted that temperatures reached within a firing structure affect more the archaeointensities than the archaeodirections. The reason is that the latter can be obtained even from samples carrying only a partial thermoremanence, whereas for archaeointensities a full thermoremanence carried by the clay is required. Therefore, we will focus on the possible relation of firing temperatures to the success or failure of the archaeointensity experiment.

In all studies dealing with thermal distributions within kilns (see Introduction), the temperatures reached had been examined through the magnetic properties of samples. The present study used a different approach, by incorporating mineralogy and petrography, and we will apply the derived results to discuss our archaeointensity experiments. For the majority of samples (18 out of 20), the estimation of their firing conditions and the quantification of their neoformed iron oxides have a good correlation with the archaeointensity results. More specifically, when the content of magnetic minerals (hematite, magnetite, titanomagnetite, magnesioferrite) is $>1 \mathrm{wt} \%$ the intensity experiments were successful.
A nonsystematic correlation appears for a few samples (SO3-5a, PAR3-6b), which yielded failed intensity data despite the fact that the iron oxide content is high enough, especially in SO3-5a where the hematite amount is $6.8 \mathrm{wt} \%$. One reason for these failures might be the composition of hematite, which is not pure hematite but titanohematite (solid solution hematite-ilmenite) and possibly prohibits the successful determination of intensity because of its very low Curie temperatures, ranging from ca. 70 to $220^{\circ} \mathrm{C}$. The last hypothesis requires an SEM-EDS analysis in combination with X-ray diffraction analysis and petrographic observation for a more careful examination of Fe-bearing minerals (i.e. the presence of solid solutions, exsolution-dissolution phenomena, and grain size). At the present stage, it appears that the use of mineralogy/petrography could greatly contribute to the preselection of samples for archaeointensity experiments, but this should be performed in tandem with traditional rock-magnetic studies, because a general protocol is for the moment difficult to establish.

\section{Archaeomagnetic Dating}

One of the key contributions of archaeomagnetism to archaeological research is the ability to date an archaeological feature. This issue will be further developed as follows.

Table 5 provides a compilation of archaeomagnetic data from a broad timespan, ranging from Late Classical-Hellenistic to Early Roman kilns, some of which have already been incorporated in the Greek secular variation curves (De Marco et al. 2008b, 2014; Tema et al. 2012). We have selected a broader period than the one studied here (Hellenistic-Early Roman) in order to cover potential chronological overlappings and document eventual differentiations following the archaeomagnetic dating, as the archaeological date range is often very broad.

First, a dating of all four workshops discussed here, using the Pavón-Carrasco et al. (2011) method, is presented in Figure S5. This dating was performed with the archaeo_date MATLAB routine, using the SCHA.DIF.3K geomagnetic field model (PavónCarrasco et al. 2009), with time constraints between $1000 \mathrm{BC}$ and AD 500. A 95\% probability threshold has been used for several sites, while the rest are reported at $65 \%$. The latter was chosen based on the fact that the resulting dates are more meaningful and more in accordance with the archaeological constraints; however, when reported at $65 \%$ the lower probability has to be taken into account. Then, we proceeded to the dating of six kilns (along with two more published dating results) from Table 5, which were not included in the above reference curve. Obviously, this model was chosen because it did not include either the data from the four workshops studied here nor the six data from Table 5 for which a new dating is presented.

Several degrees of convergence are observed: in most cases the calculated archaeomagnetic age is well in accordance with the archaeological one; in general, the dating accuracy (using a time constraint of 1000 BC-AD 500 and a probability threshold of 65\%) 
Table 5. Published archaeomagnetic results from Late Classical-Hellenistic and Early Roman kilns in Greece, listed according to mean archaeological age.

\begin{tabular}{|c|c|c|c|c|c|c|c|c|c|c|c|c|c|}
\hline \multirow[b]{2}{*}{$\mathrm{Nr}$} & \multirow[b]{2}{*}{ Site } & \multirow{2}{*}{$\begin{array}{l}\text { Lat. } \\
\left({ }^{\circ} \mathrm{N}\right)\end{array}$} & \multirow{2}{*}{$\begin{array}{l}\text { Long. } \\
\left({ }^{\circ} \mathrm{E}\right)\end{array}$} & \multirow[b]{2}{*}{ Str. } & \multirow{2}{*}{$\begin{array}{l}\text { Archaeological } \\
\text { age }\end{array}$} & \multicolumn{6}{|c|}{ Archaeomagnetic results } & \multirow[b]{2}{*}{ Archaeomagnetic age } & \multirow[b]{2}{*}{ Reference } \\
\hline & & & & & & $\mathrm{I}_{\mathrm{s}}\left({ }^{\circ}\right)$ & $\mathrm{D}_{\mathrm{s}}\left(^{\circ}\right)$ & $\alpha_{95}$ & $\mathrm{~N}$ & $\mathrm{~F} \pm \sigma(\mu \mathrm{T})$ & $\mathrm{n}$ & & \\
\hline 1 & Ierissos & 40.40 & 23.88 & $\mathrm{~K}$ & $470-370 \mathrm{BC}$ & - & - & - & - & $70.2 \pm 1.1$ & 4 & (561-449 BC), 354-283 BC & 7,8 \\
\hline 2 & Knossos & 35.32 & 25.20 & $\mathrm{~K}$ & $400-370 \mathrm{BC}$ & 58.4 & -8.5 & 2.7 & 17 & - & - & & $1,2,3$ \\
\hline 3 & Corinth A & 37.92 & 22.92 & $\mathrm{~K}$ & $400-330 \mathrm{BC}$ & 60.1 & -7.2 & 1.6 & 16 & - & - & & $1,4,3$ \\
\hline 4 & Olympia C & 37.50 & 21.61 & $\mathrm{~K}$ & $350-300 \mathrm{BC}$ & 56.4 & -5.2 & 2.5 & 7 & - & - & & $1,2,3$ \\
\hline 5 & Athens & 38.00 & 23.70 & $\mathrm{~K}$ & $400-300 \mathrm{BC}$ & 58.7 & -6.9 & 2.9 & 11 & - & - & 388-246 BC, (214-191 BC) & 1 \\
\hline 6 & Amphipolis 1 & 40.50 & 23.60 & CK & $473-173 \mathrm{BC}$ & 60.1 & -7.4 & 3.9 & 7 & $74.1 \pm 3.9$ & 5 & & 6,7 \\
\hline 7 & Corinth B & 37.92 & 22.92 & $\mathrm{~K}$ & $330-300 \mathrm{BC}$ & 57.2 & -6.4 & 1.1 & 11 & - & - & & $1,4,3$ \\
\hline 8 & Edessa & 40.80 & 22.05 & $\mathrm{~K}$ & $300-200 \mathrm{BC}$ & 57.4 & -10.5 & 1.7 & 11 & $66.8 \pm 5.0$ & 7 & $391-246 \mathrm{BC},(67 \mathrm{BC}-\mathrm{AD} 111)^{* 2}$ & 5 \\
\hline 9 & Pentavrissos & 40.45 & 21.16 & $\mathrm{~K}$ & $300-200 \mathrm{BC}$ & 59.5 & -19.8 & 2.8 & 7 & $66.2 \pm 3.3$ & 4 & $397-278 \mathrm{BC}^{* 2}$ & 5,8 \\
\hline 10 & Europos & 40.80 & 22.00 & $\mathrm{~K}$ & $330-70 \mathrm{BC}$ & 60.8 & -4.7 & 2.2 & 8 & - & - & & 1,9 \\
\hline 11 & Pella 1 & 40.70 & 22.33 & $\mathrm{~K}$ & $330-70 \mathrm{BC}$ & 62.5 & -5.2 & 3.6 & 10 & - & - & & $1,9,3$ \\
\hline 12 & Kato Achaia 3 & 38.15 & 21.55 & CK & $323-31 \mathrm{BC}$ & 56.5 & -7.0 & 2.7 & 8 & $61.3 \pm 6.0$ & 12 & $87 \mathrm{BC}-\mathrm{AD} 121$ & 11,12 \\
\hline 13 & Kato Achaia 5 & 38.15 & 21.55 & CK & $323-31 \mathrm{BC}$ & 57.3 & -9.9 & 2.4 & 9 & $62.4 \pm 5.2$ & 11 & $70 \mathrm{BC}-\mathrm{AD} 20$ & 11,12 \\
\hline 14 & Avlis & 38.50 & 23.67 & $\mathrm{~K}$ & 600 BC-AD 100 & 62.1 & -6.8 & 4.5 & 6 & - & - & $473-63 \mathrm{BC}^{* 2}$ & 1 \\
\hline 15 & Amphipolis 2 & 40.82 & 23.85 & $\mathrm{~K}$ & $400 \mathrm{BC}-\mathrm{AD} 100$ & - & - & - & - & $62.3 \pm 2.6$ & 2 & & 6,8 \\
\hline 16 & Delos A & 37.38 & 25.29 & $\mathrm{~K}$ & $70-68 \mathrm{BC}$ & 55.2 & -5.5 & 2.5 & 8 & - & - & & $1,4,3$ \\
\hline 17 & Samothraki & 40.48 & 25.52 & $\mathrm{~K}$ & 300 BC-AD 200 & - & - & - & - & $63.9 \pm 2.8$ & 15 & 303-118 BC, AD 94-150*1 & 7,8 \\
\hline 18 & Kalo Horio & 35.07 & 26.14 & $\mathrm{~K}$ & $110 \mathrm{BC}-\mathrm{AD} 90$ & - & - & - & - & $50.5 \pm 6.6$ & 7 & & 10 \\
\hline 19 & Pella 3 & 40.75 & 22.50 & $\mathrm{~K}$ & $70 \mathrm{BC}-\mathrm{AD} 100$ & 65.0 & -6.0 & 9.0 & 4 & - & - & & 9 \\
\hline 20 & Kato Chorio & 35.10 & 25.71 & PK & AD 0-300 & 43.0 & -2.3 & 1.9 & 20 & - & - & & $1,4,3$ \\
\hline 21 & Aegira A & 38.10 & 22.42 & $\mathrm{~K}$ & AD 100-300 & 50.5 & -2.3 & 2.1 & 30 & - & - & & 1 \\
\hline
\end{tabular}

Note: Nr: site reference number (see Figure S1); Str.: type of studied structure (K=kiln, $\mathrm{CK}=$ ceramic kiln); Archaeological age: absolute date based on archaeological constraints; Archaeomagnetic results: $\mathrm{I}_{\mathrm{s}}\left({ }^{\circ}\right)$ and $\mathrm{D}_{\mathrm{s}}\left({ }^{\circ}\right)$ : inclination and declination of the mean site direction, $\alpha_{95}: 95 \%$ confidence limit from Fisher statistics, N: number of samples used for the calculation of the archaeomagnetic mean direction, $\mathrm{F} \pm \sigma(\mu \mathrm{T})$ : mean intensity value and standard deviation, $\mathrm{n}$ : number of samples used for the calculation of the mean archaeointensity; Archaeomagnetic age: absolute date derived from archaeomagnetic dating, using the Pavón-Carrasco et al. (2011) method and Pavón-Carrasco et al. (2009) model (for the sites that have not been included in the model), in parentheses the not selected period because of incompatibility with archaeological information; Reference: each number corresponds to the reference for the archaeomagnetic direction and archaeointensity datum (see below). For the archaeomagnetic dating, a time interval constraint of 1000 BC-AD 500 (exception *1:600 BC-AD 300) and a 65\% or 95\% (*2) probability threshold has been employed. References: 1: Evans (2006); 2: Evans et al. (1995); 3: Evans (1994); 4: Evans and Mareschal (1988); 5: De Marco (2007); 6: Spatharas et al. (2000); 7: Spatharas et al. (2011); 8: Spatharas (2005); 9: Evans and Kondopoulou (1998); 10: Liritzis and Thomas (1980); 11: Tema (2013); 12: Tema et al. (2014).

Figure 5. Schematic representations of the structural parts of a circular and a rectangular kiln (from Hasaki 2002); the corresponding terms generally apply to any firing structure (kilns, ovens and furnaces). Estimated temperatures (Table 3) are denoted as follows: underlined for Katerini, gray for Olympiada, parentheses for Polymylos, plain text for Paros.
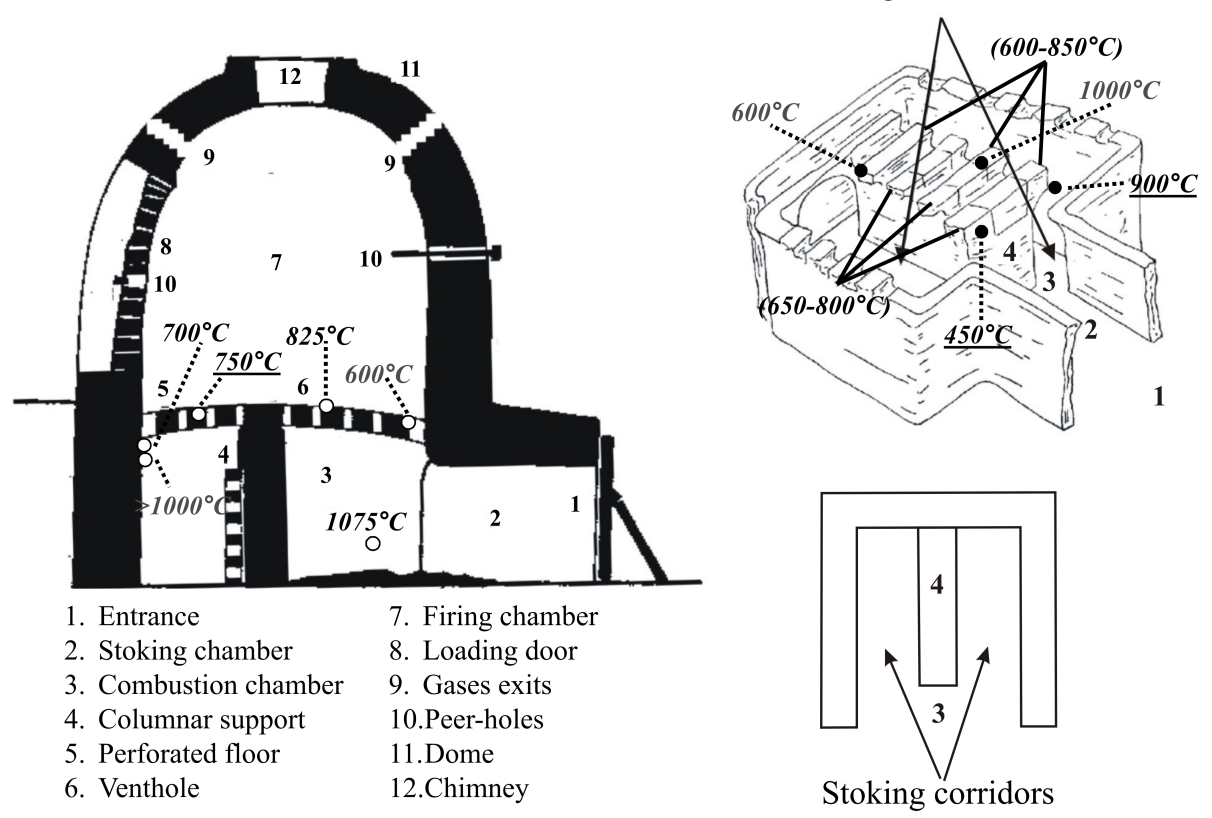
is ca. 40 years, with the better results obtained where both directional and intensity data are available, though this is not always the case, e.g. Nr 9 in Table 5. It is noteworthy that for some kilns archaeomagnetism improved the archaeological dating $(\mathrm{Nr} \mathrm{12}, 13)$, whereas in others it provided a new and important result $(\mathrm{Nr} 5,14)$. Especially in Olympiada, where the three kilns were dated separately (Table 1), the archaeomagnetic dating results reinforce the conclusion that they exhibit a concurrent end of use. In some other cases, the archaeomagnetic age has "shifted" the archaeological one to a different period. As a general remark, the two ages should be examined closely together, especially when the archaeological constraints are very precise. Independent datings provided by other physical methods might also be used for further constraints of the archaeomagnetic method (Aidona et al. 2013).

\section{CONCLUSIONS}

In the four studied sites, suitable material was found for archaeomagnetic analysis, but to a variable extent. The archaeomagnetic directions were generally well grouped, with well-defined inclinations and declinations. Several successful laboratory experiments provided reliable archaeointensity results (De Marco et al. 2008a, b; Spatharas et al. 2011). In cases of failure during the relevant experiment, the classical rock-magnetic protocols for sample preselection proved to be insufficient for reducing this failure, as suggested by Morales et al. (2011). Possible explanations could be found among the mineralogical composition and the clay paste preparation of the samples as well as their firing conditions. The former is directly related to the geological environment of the area because it provides the raw material that is crucial for the quality of the samples. For example, in Katerini almost all samples were favorable for our analysis and this could be related to their sedimentary context. Conversely, the clay mixture of Olympiada has abundant and coarser grains of quartz and feldspars, which make treatment of samples impossible, a problem not observed in the fine textured Paros' samples because of the better clay paste preparation (i.e. crushing) by potters. The additional magnetic experiments, along with the information derived from the archaeometric study, helped to clarify the samples' behavior during heating and provided a valuable input in establishing the firing history of each kiln. Because of the variety of kilns forms, a more general pattern could be drawn (Figure 5). Our suggestion is that the success of archaeointensity determinations in baked clay products and structures, sensu largo, could increase if a preliminary screening of the geological materials is carried out, including consideration of firing temperatures and burial conditions. Our latest research focuses on the application of this procedure to pottery and ceramic products (Kondopoulou et al. 2014).

The archaeomagnetic dates produced in this study, based on reliable results, improved the archaeological age estimations for six sites. Finally, we demonstrated that, given the numerous archaeological finds associated with heating (e.g. kilns, pottery, bricks, burnt soils) in the research field, the collaboration of archaeomagnetism experts with other scientists (geologists, physicists, chemists, dendrochronologists) will help refine our chronometric methods.

\section{ACKNOWLEDGMENTS}

Part of this work has been carried out through the support of European Union contract No. HPRN-CT-2002-00219 (Archaeomagnetic Applications for the Rescue of Cultural Heritage, AARCH). The authors would like to thank the archaeologists Dr. G. Karamitrou-Mendessidi and M. Lykiardopoulou (Polymylos), M. Bessios and E. Gerofoka (Katerini), K. Sismanidis (Olympiada), and Y. Kourayios (Paros) who have provided permissions and valuable information for the studied archaeological sites. Dr. Maxime Le Goff is warmly acknowledged for performing intensity measurements with the Triaxe magnetometer at St. Maur (France), as well as the initiation of the first author to the method.

\section{REFERENCES}

Aidona, E., R. Scholger, H. J. Mauritsch, and M. Perraki, 2008. Remanence acquisition in a Roman-style gold furnace. Physics and Chemistry of the Earth 33(6-7):438-448.

Aidona, E., D. Kondopoulou, M. Alexandrou, and N. Ioannidis, 2010. Archaeomagnetic studies in kilns from N. Greece. Bulletin of the Geological Society of Greece 43(4):1888-1897.

Aidona, E., G. Polymeris, D. Kondopoulou, N. Ioannidis, and P. Macridis, 2013. Archaeomagnetic and thermoluminescence dating of historical kilns from $\mathrm{N}$. Greece. IAGA, Mexico, Abstract Volume; pp. 144.

Aitken, M. J., 1999. Archaeological dating using physical phenomena. Reports on Progress in Physics 62(9):1333-1376.

Catanzariti, G., G. McIntosh, M. Gómez-Paccard, V. C. Ruiz-Martínez, M. L. Osete, A. Chauvin, and the AARCH Scientific Team, 2008. Quality control of archaeomagnetic determination using a modern kiln with a complex NRM. Physics and Chemistry of the Earth 33(6-7):427-437.

Chauvin, A., Y. Garcia, Ph. Lanos, and F. Laubenheimer, 2000. Paleointensity of the geomagnetic field recovered on archaeomagnetic sites from France. Physics of the Earth and Planetary Interiors 120(1-2):111-136.

Coe, R. S., S. C. Grommé, and E. A. Mankinen, 1978. Geomagnetic paleointensities from radiocarbon-dated lava flows on Hawaii and the question of the Pacific nondipole low. Journal of Geophysical Research 83(B4):1740-1756.

De Marco, E., 2007. Complete Magnetic and Archaeomagnetic Measurements in Archaeological Sites: Contribution to the SVC for Greece. Ph.D. thesis, Aristotle University of Thessaloniki, Greece, 283 pp. (in Greek and English).

De Marco, E., S. Spassov, D. Kondopoulou, I. Zananiri, and E. Gerofoka, 2008a. Archaeomagnetic study and dating of a Hellenistic site in Katerini (N. Greece). Physics and Chemistry of the Earth 33(6-7):481-495.

De Marco, E., V. Spatharas, M. Gómez-Paccard, A. Chauvin, and D. Kondopoulou, 2008b. New archaeointensity results from archaeological sites and variation of the geomagnetic field intensity for the last 7 millennia in Greece. Physics and Chemistry of the Earth 33(6-7):578-595.

De Marco, E., E. Tema, Ph. Lanos, and D. Kondopoulou, 2014. An updated catalogue of Greek archaeomagnetic data for the last 4500 years and a directional secular variation curve. Studia Geophysica et Geodetica 58(1):127-147.

Donadini, F., M. Korte, and C. G. Constable, 2009. Geomagnetic field for 0-3 ka: 1. New data sets for global modelling. Geochemistry, Geophysics, Geosystems 10:Q06007, doi:10.1029/2008GC002295.

Evans, M. E., 1994. Recent archaeomagnetic investigations in Greece and their geophysical significance. In Proceedings of the 2nd Conference of the Hellenic Geophysical Society; pp. 578-585. Florina, Greece.

Evans, M. E., 2006. Archaeomagnetic investigations in Greece and their bearing on geomagnetic secular variation. Physics of the Earth and Planetary Interiors 159(1-2):90-95.

Evans, M. E., and D. Kondopoulou, 1998. Archaeomagnetism in Macedonia, Greece: A progress report. Physics and Chemistry of the Earth 23(910):1027-1028. 
Evans, M. E., and M. Mareschal, 1988. Secular variation and magnetic dating of fired structures in Greece. In Proceedings of the 26th International Archaeometry Symposium, edited by R. M. Farquhar, R. G. V. Hancock, and L. A. Pavlish; pp. 75-79. University of Toronto.

Evans, M. E., R. E. Jones, S. Papamarinopoulos, D. Walton, J. Perreault, and Ch. Spais, 1995. New archaeomagnetic results from Greece. In Archaeometry Conference No 2; pp. 313-320. April 19, 1995, Delphi, Greece.

Fisher, R. A., 1953. Dispersion on a sphere. Proceedings of the Royal Society of London A 217(1130):195-305.

Genevey, A., Y. Gallet, C. Constable, M. Korte, and G. Hulot, 2008. ArcheoInt: An upgraded compilation of geomagnetic field intensity data for the past ten millennia and its application to recovery of the past dipole moment. Geochemistry, Geophysics, Geosystems 9:Q04038, doi:10.1029/2007GC001881.

Gómez-Paccard, M., A. Chauvin, Ph. Lanos, J. Thiriot, and P. Jiménez-Castillo, 2006. Archeomagnetic study of seven contemporaneous kilns from Murcia (Spain). Physics of the Earth and Planetary Interiors 157(1-2):16-32.

Gómez-Paccard, M., A. Chauvin, Ph. Lanos, Ph. Dufresne, M. Kovacheva, M. J. Hill, E. Beamud, S. Blain, A. Bouvier, P. Guibert, and Archaeological Working Team, 2012. Improving our knowledge of rapid geomagnetic field intensity changes observed in Europe between 200 and 1400 AD. Earth and Planetary Science Letters 355-356:131-143.

Grim, R. E., 1968. Clay Mineralogy. 2nd edition, McGraw-Hill, New York.

Hasaki, E., 2002. Ceramic Kilns in Ancient Greece: Technology and Organization of Ceramic Workshops. Ph.D. thesis, University of Cincinnati.

Jones, T., 1993. Practical Tips for Potters Making Improved Cooking Stoves. Hofman Systems Engineering, Schiedam, the Netherlands.

Jordanova, N., M. Kovacheva, I. Hedley, and M. Kostadinova, 2003. On the suitability of baked clay for archaeomagnetic studies as deduced from detailed rock-magnetic studies. Geophysics Journal International 153(1):146-158.

Kirschvink, J., 1980. The least-squares line and plane and the analysis of paleomagnetic data. Geophysical Journal Royal Astronomical Society 62(3):699718.

Kondopoulou, D., M. Gomez-Paccard, E. Aidona, C. Rathosi, C. Carvalo, E. Tema, and G. Eftimiadis, 2014. Prehistoric ceramics as recorders of the earth's magnetic field intensity: Case studies from North-Central Greece and a multidisciplinary approach for material selection. Geophysical Research Abstracts 16:EGU2014-9775.

Korte, M., A. Genevey, C. G. Constable, and E. Schnepp, 2005. Continuous geomagnetic field models for the past 7 millennia: 1. A new global data compilation. Geochemistry, Geophysics, Geosystems 6:Q02H15, doi:10.1029/2004GC000800.

Kovacheva, M., N. Jordanova, and V. Karloukovski, 1998. Geomagnetic field variations as determined from Bulgarian archaeomagnetic data. Part II. The last 8000 years. Survey in Geophysics 19(5):431-460.

Le Goff, M., and Y. Gallet, 2004. A new three-axis vibrating sample magnetometer for continuous high-temperature magnetization measurements: Applications to paleo- and archeointensity determinations. Earth and Planetary Science Letters 229(1-2):31-43.

Le Goff, M., Y. Gallet, A. Genevey, and N. Warmé, 2002. On archaeomagnetic secular variation curves and archeomagnetic dating. Physics of the Earth and Planetary Interiors 134(3-4):203-211.

Liritzis, Y., and R. C. Thomas, 1980. Palaeointensity and thermoluminescence measurements on Cretan Kilns from 1300 to 2000 BC. Nature 283(5742):54-55.

Mackenzie, R. C., 1957. Differential Thermal Investigation of Clays. Mineralogical Society, London.

Morales, J., A. Goguitchaichvili, B. Aguilar-Reyes, M. Pineda-Duran, C. Camps, C. Carvallo, and M. Calvo-Rathert, 2011. Are ceramics and bricks reliable absolute geomagnetic intensity carriers? Physics of the Earth and Planetary Interiors 187(3-4):310-321.

Murad, E., and U. Wagner, 1998. Clays and clay minerals: The firing process. Hyperfine Interactions 117(1-4):337-356.

Nodari, L., E. Marcuz, L. Maritan, C. Mazzoli, and U. Russo, 2007. Hematite nucleation and growth in the firing of carbonate-rich clay for pottery production. Journal of the European Ceramic Society 27(16):4665-4673.

Pavón-Carrasco, F. J., M. L. Osete, J. M. Torta, and L. R. Gaya-Piqué, 2009. A regional archeomagnetic model for Europe for the last 3000 years, SCHA. DIF.3K: Applications to archeomagnetic dating. Geochemistry, Geophysics, Geosystems 10:Q03013, doi:10.1029/2008GC002244.
Pavón-Carrasco, F. J., M. L. Osete, and J. M. Torta, 2010. Regional modelling of the geomagnetic field in Europe from 6000 to 1000 BC. Geochemistry, Geophysics, Geosystems 11:Q11008, doi:10.1029/2010GC003197.

Pavón-Carrasco, F. J., J. Rodríguez-González, M. L. Osete, and J. M. Torta, 2011. A Matlab tool for archaeomagnetic dating. Journal of Archaeological Science 38:408-419.

Prévot, M., E. A. Mankinen, R. S. Coe, and C. S. Grommé, 1985. The Steens Mountain (Oregon) geomagnetic polarity transition 2. Field intensity variations and discussion of reversal models. Journal of Geophysical Research 90(B12): 10,417-10,448.

Rathossi, C., and Y. Pontikes, 2010a. Effect of firing temperature and atmosphere on ceramics made of NW Peloponnese clay sediments. Part I: Reaction paths, crystalline phases, microstructure and colour. Journal of the European Ceramic Society 30(9):1841-1851.

Rathossi, C., and Y. Pontikes, 2010b. Effect of firing temperature and atmosphere on ceramics made of NW Peloponnese clay sediments: Part II. Chemistry of pyrometamorphic minerals and comparison with ancient ceramics. Journal of the European Ceramic Society 30(9):1853-1866.

Schwedt, A., H. Mommsen, N. Zacharias, I. Buxeda, and J. Garrigos, 2006. Analcime crystallization and compositional profiles-Comparing approaches to detect post-depositional alterations in archaeological pottery. Archaeometry 48(2):237-251.

Shoval, S., M. Gaft, P. Beck, and Y. Kirsh, 1993. The thermal behaviour of limestone and monocrystalline calcite temper during firing and their use in ancient vessels. Journal of Thermal Analysis 40(1):263-273.

Spassov, S., and J. Hus, 2006. Estimating baking temperatures in a Roman pottery kiln by rock magnetic properties: Implications of thermochemical alteration on archaeointensity determinations. Geophysical Journal International 167(2):592-604.

Spatharas, V., 2005. Archaeomagnetic and Magnetic Measurements in Archaeological Materials in Macedonia and Thraki (N. Greece). Ph.D. thesis, Aristotle University of Thessaloniki, Greece, $179 \mathrm{pp}$. (in Greek).

Spatharas, V., D. Kondopoulou, I. Liritzis, and G. N. Tsokas, 2000. Archaeointensity results from two ceramic kilns from N. Greece. Journal of the Balkan Geophysical Society 3(4):67-72.

Spatharas, V., D. Kondopoulou, E. Aidona, and K. G. Efthimiadis, 2011. New magnetic mineralogy and archaeointensity results from Greek kilns and baked clays. Studia Geophysica et Geodaetica 55(1):131-157.

Spear, F. S., 1995. Metamorphic Phase Equilibria and Pressure-Temperature-Time Paths. Mineralogical Society of America, Washington, DC, 799 pp.

Stephenson, A., S. Sadikun, D. K. Potter, 1986. A theoretical and experimental comparison of the anisotropies of magnetic susceptibility and remanence in rocks and minerals. Geophysical Journal of the Royal Astronomical Society 84(1):185-200.

Tema, E., 2013. Detailed archaeomagnetic study of a ceramic workshop at Kato Achaia: New directional data and archaeomagnetic dating in Greece. Bulletin of the Geological Society of Greece XLVII:1-10.

Tema, E., and D. Kondopoulou, 2011. Secular variation of the Earth's magnetic field in the Balkan region during the last eight millennia based on archaeomagnetic data. Geophysical Journal International 186(2):603-614.

Tema, E., M. Gómez-Paccard, D. Kondopoulou, and Y. Almar, 2012. Intensity of the Earth's magnetic field in Greece during the last five millennia: New data from Greek pottery. Physics of the Earth and Planetary Interiors 202-203:14-26.

Tema, E., G. Polymeris, J. Morales, A. Goguitchaichvili, and V. Tsaknaki, 2014. Dating of ancient kilns: A combined archaeomagnetic and thermoluminescence analysis applied to a brick workshop at Kato Achaia, Greece. Journal of Cultural Heritage, doi:10.1016/j.culher.2014.09.013.

Thellier, E., 1981. Sur la direction du champ magnétique terrestre en France durant les deux derniers millénaires. Physics of the Earth and Planetary Interiors 24(2-3):89-132.

Thellier, E., and O. Thellier, 1959. Sur l'intensité du champ magnétique terrestre dans le passé historique et géologique. Annales de Géophysique 15:285-376.

Veitch, R. J., I. G. Hedley, and J. J. Wagner, 1984. An investigation of the intensity of the geomagnetic field during Roman times using magnetically anisotropic bricks and tiles. Archive des Sciences Genève 37(3):359-373.

Whitbread, I. K., 1995. Greek Transport Amphorae: A Petrological and Archaeological Study. Occasional Papers, volume 4, British School at Athens Fitch Laboratory, Exeter, UK, 453 pp. 